\title{
A INVASÃO DAS TERRAS KAINGANG NOS CAMPOS DE PALMAS. O PROCESSO CONTRA A LIDERANÇA INDÍGENA VITORINO CONDÁ (1839-44)
}

\author{
Almir Antonio de Souza ${ }^{1}$
}

\begin{abstract}
RESUMO
0 objetivo do estudo é analisar na documentação do período, como se deu o processo judicial contra a liderança indígena Vitorino Condá e a invasão das terras do povo originário sob seu comando na região compreendida entre os campos de Palmas no Planalto meridional. Na invasão dos campos de Palmas, analiso o envolvimento das autoridades e fazendeiros imperiais com o processo de tentativa de controle, domínio e expulsão de Vitorino Condá e seus comandados e demonstro a política desenvolvida por essas autoridades e fazendeiros, bem como as formas utilizadas para afastar Condá de seus lugares de morada através de um processo civil de justificação. Tornase importante demonstrar o processo de expulsão do povo Kaingang liderado por Vitorino Condá, dos Campos de Palmas. Nas lutas por suas terras e no confronto com fazendeiros e autoridades imperiais durante a expansão luso-brasileira, há a afirmação de povoados e vilas e assinalam-se as estratégias políticas de índios e não índios nesses lugares.
\end{abstract}

Palavras-Chave: História indígena. Kaingang. Palmas. Vitorino Condá.

\footnotetext{
${ }^{1}$ Doutor em História pela UFSC e pesquisador do Departamento de História da UNICENTRO, no PR. Bolsista CAPES, E-mail para contato: almirppo@gmail.com
} 


\section{THE INVASION OF THE KAINGANG LANDS IN CAMPOS DE PALMAS. THE PROCESS AGAINST THE INDIGENOUS LEADERSHIP VITORINO CONDÁ (1839-44)}

\section{ABSTRACT}

The objective of the study is to analyze the documentation of the period, also investigating about how was the judicial process against the indigenous leadership Vitorino Condá and the invasion of the indigenous people lands under his command in the region between the Campos de Palmas in southern Brazilian Plateau. The invasion of Palmas fields analyze the involvement of the imperial authorities and farmers in the process of trying to control, dominate and expulse Vitorino Condá and his men. The article also demonstrate the policy pursued by the authorities and farmers in order to remove Condá from their home places through a civil process of justification. To understand that, it is important to demonstrate the process of expulsion the Kaingang people led by Vitorino Condá from Palmas fields. In the struggle for their land, supported by confronting farmers and imperial authorities during the Luso-Brazilian expansion, there is the assertion of towns and villages, marking up the political strategies of Indigenous and non-Indiginous people in these places.

Keywords: Indigenous history. Kaingang. Palmas. Vitorino Condá.

\section{INTRODUÇÃO}

$\mathrm{N}$

o Brasil Império, durante os anos de 1839 e 1844, as terras indígenas no entorno de Guarapuava no Planalto Meridional passam a ser objeto de invasão pela expansão luso-brasileira. Elas constituíam uma extensa região que compreendia os campos de Palmas e alimentava a ambição de vários fazendeiros do Planalto Meridional. No entanto, eram também lugar de lideranças como Vitorino Condá e nelas viviam vários grupos indígenas (MOTA, 2000). Os fazendeiros, e autoridades imperiais desejavam essas terras e entendiam que os povos indígenas que nelas viviam deveriam ser integrados as vilas e cidades, ou afugentados, ou aldeados, ou simplesmente escravizados e eliminados.

A investigação que apresento tenta demonstrar as lutas dos índios do Planalto Meridional, bem como aquelas empreendidas por uma de suas mais expressivas lideranças - o Kaingang Vitorino Condá. Entre o ano de 1839 e a retirada dos povos comandados por Condá dos campos de Palmas, em 1844, faço um apanhado dos documentos e relatos que demonstra esta operação de expulsão dos povos originários que habitavam esses lugares. 
Na primeira parte do artigo, que se detém na invasão dos campos de Palmas, analiso o envolvimento das autoridades e de fazendeiros imperiais com 0 processo de tentativa de controle, domínio e expulsão de Vitorino Condá e seus comandados. Na segunda parte, demonstro a política desenvolvida por essas autoridades e fazendeiros e as formas utilizadas para afastar Condá de seus campos de morada através de um processo civil de justificação. As fontes utilizadas no trabalho foram pesquisadas no Arquivo Público do Estado de São Paulo - APESC, e Arquivo Nacional na cidade do Rio de Janeiro- AN. As leis, relatos e relatórios de Presidente da Província publicados no Brasil Império foram pesquisados na rede mundial de computadores. ${ }^{2}$

\section{A invasão dos Campos de Palmas e o KAINGANG VITORINO CONDÁ}

Os campos de Palmas estavam a sudoeste de Guarapuava e, além de representar um espaço propício para a criação de animais que não parava de crescer, era também o início do novo caminho para as Missões. Esse território conhecido desde a ocupação de Guarapuava no início do século XIX, já era cobiçado pelos fazendeiros guarapuavanos. Em 1839, fazendeiros de vários lugares, como a Vila do Príncipe, Palmeira e Curitibanos passaram a invadir esses campos. Nesse momento, um dos principais interessados nas terras era Pedro de Siqueira Cortez.

Pedro de Siqueira Cortez havia chegado a esses campos em 1839, na intenção de possuir terras e criar animais. No início, Pedro da Siqueira tentou juntar-se a uma sociedade de exploradores que sairia de Guarapuava comandada por José Ferreira dos Santos, mas como não conseguiu, montou sua própria sociedade e com uma comitiva abriu uma nova picada a facão, saindo de freguesia de Palmeira até os campos de Palmas. De acordo com os escritos de um dos escolhidos como mediador da divisão de terras, José Joaquim Pinto Bandeira, os exploradores permaneceram abrindo picadas, queimando a mata, abrindo os campos, recolhendo animais e construindo currais e casas. Vinham também exploradores de outros lugares próximos como Curitibanos, De acordo com estes escritos: "como não havia uma decisão sobre a sorte dos campos, muita ocupação

\footnotetext{
2 Os sites pesquisados foram: Coleção das Leis do Império, site da Câmara Federal, http://www.2.camara.gov.br; site da Revista do Instituto Histórico e Geográfico Brasileiro, http://www.ihgb.org.br/rihgb e site da Universidade de Chicago, http: //www.crl.uchicago.edu/content/provopen.htm.
} 
era feita irregularmente, e os que chegavam iam colocando animais, casa e currais, sem respeitar limites." (BANDEIRA, 1851, p. 426).

Cada um à sua maneira montava a casa e a fazenda onde lhe parecia mais conveniente. As discussões entre os diversos exploradores eram resolvidas com muita briga, "deixando a decisão do negócio ao arbítrio das armas; casas houve que foram derrubadas e currais arrasados (BANDEIRA, 1851, p. 428).” Em razão da violência exacerbada na região, por decisão dos povoadores, estabeleceu-se que eles deveriam eleger dois árbitros para se decidir a demarcação e os limites de terra que pertenceriam a cada explorador. A eleição recaiu sobre 0 capitão Domingos Ignácio de Araújo e o Alferes José Caetano de Oliveira, mas como ambos não podiam deslocar-se até os campos de Palmas, João da Silva Carrão e José Joaquim Pinto Bandeira foram escolhidos para a tarefa. Ambos eram moradores de Curitiba e deveriam resolver a escalada de violência na região, por meio da divisão das terras pelos interessados, o que foi feito. A partir do segundo semestre de 1840, já estavam os campos divididos a partir de um lajeado chamado 'As Caldeiras', ficando José Ferreira dos Santos com as terras voltadas para o nascente e Pedro da Siqueira Cortez com as terras voltadas para o poente (BANDEIRA, 1851).

Pedro de Siqueira Cortez a partir de 1841 assumiu o comando da Companhia de Permanentes da Polícia em Palmas, substituindo o capitão Hermógenes Carneiro Lobo Ferreira. No ano de 1843, o mesmo capitão necessitou da ajuda de Vitorino Condá e convenceu o índio a tentar, com ele, resgatar 0 tropeiro (negociante de animais), capitão José de Sá Soutto-Maior das mãos de indígenas que habitavam as proximidades. Nessa época, a tensão entre índios e não índios era muito grande, devido à disputa pelas terras da região. Eram comuns que os índios "sequestrassem" alguns não índios, após invadirem e saquearem suas casas e comitivas. Acreditava-se que esse era o caso de SouttoMaior, que em 23 de julho de 1832, nas missões em São Pedro do Rio Grande do Sul, teve atacada e destruída toda sua comitiva. Não sendo encontrado o cadáver do infeliz capitão entre os demais, a crença geral que se encontrava cativo dos índios ganhou força. Ainda de acordo com Bandeira (1851), da missão de resgatar povoadores que se encontravam cativos dos índios resultou um retorno a Palmas com sete crianças brancas, e mais uma comitiva de índios que resolveu acompanhar Vitorino Condá para habitar próximo ao povoamento de Palmas.

Depois do retorno de Vitorino e Hermógenes com as sete crianças brancas para 0 povoado de Palmas, o comandante da Companhia de Permanentes estacionada em Palmas - Pedro de Siqueira Cortez-, com receio do grande número 
de Índios que estavam em Palmas, mandou vir auxílio de homens armados de Guarapuava.

Nessas circunstâncias, houve a perseguição aos índios recém chegados em campos de Palmas. Aproveitando o momento em que os guerreiros de Vitorino decidiram sair do aldeamento, argumentando a necessidade de realizar uma caçada, Pedro de Siqueira Cortez mandou seus homens no encalço dos guerreiros, e após perseguirem ao grupo de Condá, assassinaram, sem qualquer resistência, mais de vinte dos Indígenas:

\begin{abstract}
A Presença dos Indios causou fortes aprehensões ao Ex-Commandante da Companhia de Permanentes, que, em vês d'agasalhal-os, mostrarlhes affecto, e disposições pacificas, pelo contrario apressou-se em deprecar auxilio de força armada as auctoridades, de Guarapuava, havendo logo quem declarasse aos Indios ser destinada essa força para matal-os, com o que ficaram aterrorisados, e receosos de traição, muito contribuindo para isso seu caracter naturalmente desconfiado e suspeitozo. Apenas houve noticia de aproximar-se á Palmas 0 deprecado auxilio, os Indios pedem licença ao Ex-Commandante, para irem a caça, e em virtude d'ella retirao-se, tomando duas veredas diversas, o que fez crer á este a tentativa de algum assalto. Immediatamente determina 0 mesmo Ex-commandante a marcha d'uma escolta sufficiente para 0 lado, por onde seguira 0 maior numero de índios, com ordem de trazel-os, ou matal-os; e, como impugnassem voltar, usou a escolta da segunda alternativa, e vinte tantos Indios d'ambos os sexos, inermes, sem opporem resistencia activa, foram assassinados. No fim de dous mezes, impellidos pelo desejo de vingança, avanção alguns índios sobre a povoação, e matarão três pessoas ${ }^{3}$.
\end{abstract}

As ocorrências tiveram lugar, na nascente povoação de Palmas, em agosto de 1843, com 0 assassinato de mais de vinte índios, por parte da escolta armada do comandante da Companhia dos Permanentes estacionada nos campos de Palmas. Em retaliação, os índios atacaram o povoado de Palmas, matando três pessoas, e a notícia de que os índios estavam preparando uma invasão com um grande número de guerreiros, deixou em polvorosa o povoamento, sendo que

\footnotetext{
${ }^{3}$ Discurso do presidente da província de São Paulo Manuel Felizardo de Souza e Mello, em 07 de janeiro de 1844, por ocasião da abertura da Assembleia Provincial. São Paulo: Typografia do Governo, 1844. p. 49-50.
} 
muitas fazendas passaram a ser abandonadas. Para conter tal ânimo, o governo: criou em Palmas uma Subdelegacia de Polícia, demitiu o comandante e nomeou novamente para o cargo Hermógenes Carneiro Lobo Ferreira e, como comandante dos índios, Vitorino Condá. Chama a atenção na documentação do governo com relação ao episódio dos assassinatos, a omissão do nome do comandante, que é citado apenas como o Ex-Commandante. Sabe-se, no entanto, sua identidade: ele é Pedro de Siqueira Cortez que segundo o governo da província "sem motivos legítimos, e imprudentemente provocou os Índios, levou-os ao excesso de desesperação, frustrando as vantagens que se poderia colher de seu aldeamento." (SOUZA, 2012, p. 295).

No ano seguinte, em 1844, Vitorino Condá continuou estabelecido na região entre os rios Chopin e Iguaçu. 0 retorno de Hermógenes Lobo ao comando da Companhia reforçava a posição de Vitorino nos campos e matas próximos de Palmas. No mapa a seguir que encontrei no Arquivo Nacional, confeccionado no ano de 1864 e de autoria de John Henrique Elliot, norte-americano a serviço do Barão de Antonina, indico com uma linha branca tracejada (de minha autoria) alguns lugares de deslocamento de Condá, os matos (cor verde) e campos (cor amarela) da região, além de alguns caminhos e estradas existentes, como a 'Estrada de Missões'(o trajeto abaixo apresentado só passou a existir a partir de 1845, com sua abertura efetivada por Vitorino Condá e o primogênito dos Rocha Loures- Francisco Ferreira), o 'Caminho do Sul' e a estrada da freguesia do Senhor Bom Jesus dos Campos de Palmas até Palmeira (linhas vermelhas). 
Figura 1 - Parte da Província do Paraná no Império

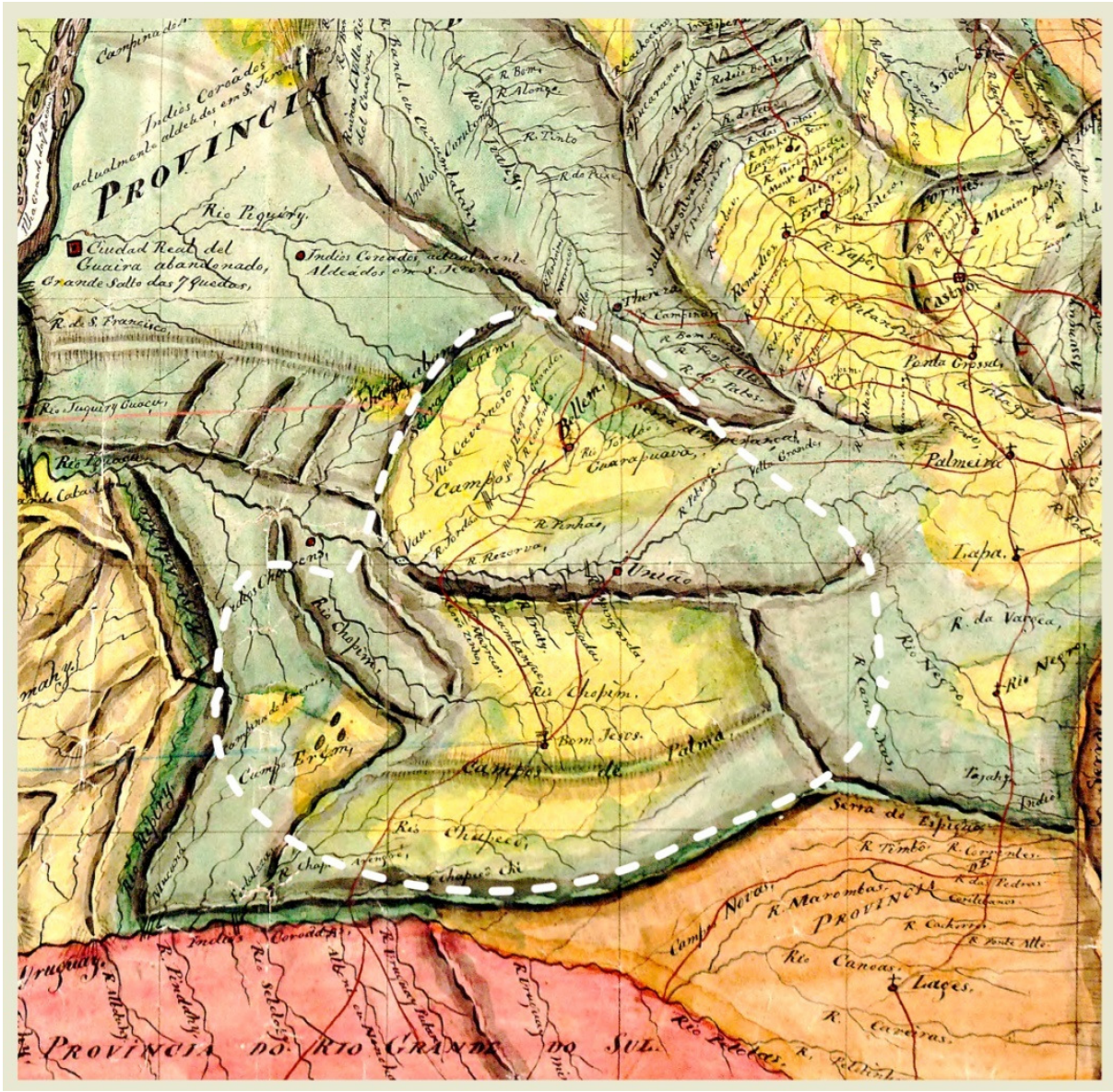

Fonte: Adaptação de Spina (2012); Seção de Mapas do Arquivo Nacional, Rio de Janeiro - RJ. Série 776.2- 9G.

\section{O Processo contra Condá}

Após o assassinato dos índios do grupo de Condá, em agosto de 1843, Pedro de Siqueira Cortez foi demitido do comando da Companhia de Permanentes Municipais estacionada nos campos de Palmas. Porém, essa demissão nada honrosa não foi aceita facilmente pelo referido Siqueira Cortez e menos ainda por seu principal aliado, que o havia designado para o comando de Palmas, o capitão 
mor comandante da povoação de Palmeira: Domingos Ignácio de Araujo. Em ofício ao Governo que tinha demitido Pedro de Siqueira, o capitão mor solicitou a restituição do mesmo ao comando, o que lhe foi negado pelo então Presidente da província de São Paulo, Joaquim José Luís de Souza. ${ }^{4}$ Mas, diante dessa negativa, Pedro de Siqueira Cortez e Domingos Ignácio de Araújo, montaram uma nova estratégia. Como o período de governo de um Presidente a frente da província, raramente se estendia por mais de dois anos e Joaquim Jose Luís de Souza tinha assumido em janeiro de 1843, era possível, dentro das expectativas, que no ano seguinte ele fosse substituído. Então, a dupla esperaria o próximo Presidente para apresentar um novo ofício e solicitar a restituição do comando da Companhia de Permanentes de Palmas.

Alguns dias após a substituição do Presidente Joaquim José Luís de Souza, no dia 09 de janeiro de 1844, Pedro de Siqueira Cortez foi até a Vila Nova do Príncipe de Santo Antonio da Lapa, a pouca distância de seu lugar de origem, onde quem mandava era Domingos Ignácio de Araújo - a freguesia de Palmeira. Chegando ao cartório da vila, junto ao escrivão Francisco Videira de Almeida, ele instaurou uma petição de justificação ao juiz municipal, o capitão Antonio Alves de Oliveira, na qual procurou justificar que os "Índios de Palmas" eram perigosos, uma vez que comandavam os ataques e assassinatos na estrada do sul e na Província de São Paulo. Além disso, essa petição ainda afirmava que o comandante desses ataques, mortes e pilhagens, em tese, era Vitorino Condá. ${ }^{5}$ A ofensiva, dessa vez, deveria ser bem documentada e estava apoiada em testemunhos que davam substância jurídica a causa. Dentro dessa visão, era normal que a formulação de perguntas para as testemunhas fossem mais afirmações do que propriamente perguntas. Os quesitos direcionados às testemunhas foram compostos da forma que segue:

\footnotetext{
${ }^{4}$ Documentos juntados pelo escrivão do Cartório de Palmeira a mando do Capitão Domingos de Araújo e anexados em ofício ao Presidente da Província, Manuel Felisardo de Souza e Mello, de 22 de maio de 1844, onde o Capitão dizia que o antecessor Presidente da Província Joaquim José Luis de Souza, não tinha atendido sua solicitação no ofício de 04 de janeiro de 1844 , de retornar 0 Comando da Cia de Permanentes abarracada nos Campos de Palmas, a Pedro de Siqueira Cortez. Seção Manuscritos. Ofícios diversos de Curitiba (1841-44). Caixa 209, pasta 4, documento 26, ordem 1004. APESP.

${ }^{5}$ De acordo com o atual Código Brasileiro do Processo Civil, em sua seção IX, entre os artigos 861866, a justificação é uma medida cautelar constituída de uma audiência de testemunhas com a finalidade de demonstrar existência de fato ou relação jurídica, pode servir como mero documento sem caráter contencioso ou como prova em processo regular. Atesta o que declaram as testemunhas perante o juiz, não se admite defesa, contrariedade ou recurso, pois não há pronúncia sobre o mérito (MACHADO, 2012).
} 
Diz Pedro de Siqueira Cortes da Freguesia de Palmeira e nesta por seu procurador, que para bem de seo direito precisa justificar o seguinte

$1^{\circ}$ Que tem havido muitas incursoens dos Índios na estrada que segue para a Provincia do Rio Grande Do Sul principalmente no matto Castelhano e em diversos pontos da Comarca de Missoens e Destrico da Vaccaria naquella Provincia, e que tem resultado muitas mortes e roubos, tanto nos viajantes como nos moradores daquele logar.

$2^{\circ}$ Que os Índios mansos de Guarapuava e Palmas tem tido grande parte em todos estes ataques roubos e assacinios e que isto hé crido geralmente.

$3^{\circ}$ Que o Índio Victorino he acuzado geralmente de ser quem dirige todos os ataques e roubos que tem havido. ${ }^{6}$

0 que se pode inferir sobre estes quesitos? Em meu entendimento, o fato e a relação jurídica que se quer mostrar nesta petição é que Vitorino Condá comandava os índios de Guarapuava e de Palmas, e ainda presidia e organizava os assaltos a moradores e tropeiros no 'Caminho do Sul' e na província de São Paulo. Na prática, responsabilizava Condá pela maioria dos assaltos, ataques, assassinatos e pilhagens desde Palmeira até Cruz Alta no distrito das Missões e, principalmente, pelos assaltos às comitivas de tropa de animais que cruzavam pela 'Estrada ou Caminho do Sul'.

No entanto, é fato que Condá tinha amealhado prestígio e respeito do governo da Província, por conta da recuperação das sete crianças brancas que estavam cativas de indígenas, enquanto Pedro de Siqueira Cortez estava desonrado em razão de sua demissão do comando em Palmas, provocado, como sabido, pelo assassinato dos índios de Condá, cometido pelos homens do ex-comandante. Para mudar isso, era necessário criar uma relação jurídica que comprovasse que 0 resgate das crianças nunca teria existido, a partir da afirmativa de que, na verdade, estas crianças estiveram cativas do próprio Condá. Além disso, há a atribuição aos índios de Palmas e Guarapuava à condição de criminosos e, como tal, tido apenas como bestas ferozes, que não deveriam ser considerados como povo ou nação. Com isso, deslegitimava-se a necessidade de respeito ao território destes indígenas, a mesmo passo que os assassinatos cometidos pelos homens de Pedro

\footnotetext{
${ }^{6}$ Processo civil de justificação instaurado por Pedro de Siqueira Cortez na Vila Nova do Príncipe (Lapa) e oitiva das testemunhas em 09 de janeiro e 27 de janeiro de 1844. Seção Manuscritos. Ofícios diversos de Curitiba (1841-44). Caixa 209, pasta 4, documento 17, ordem 1004. APESP.
} 
de Siqueira Cortez seriam justificados. Os índios, portanto, deveriam ser vistos apenas como inimigos cruéis e desnecessários à expansão luso-brasileira.

A oitiva do processo aconteceu na casa do juiz municipal, o capitão Antônio Alves de Oliveira e foram ouvidas as seguintes testemunhas:

\author{
Joaquim Paxeco da Silva Rezende \\ Clementino dos Santos Paxeco \\ Antonio dos Santos Paxeco \\ David dos Santos Paxeco \\ Manuel José Braga ${ }^{7}$
}

Quero deter-me na análise dos nomes das testemunhas acima, e, em um primeiro momento, em relação aos quatro primeiros nomes, pois verifica-se que todos pertencem a uma mesma família, os Pacheco. Os arrolados no processo, no caso em questão, são irmãos, negociantes de animais e donos de muitas comitivas de tropas. É desnecessário afirmar a importância da criação de animais no Brasil Império, principalmente quando se imagina o que representava as bestas de carga em um período, em que praticamente quase tudo era transportado sobre o lombo de bovinos e equinos. Os irmãos citados na documentação constituíam a família mais significativamente envolvida com os negócios de animais no sul da província de São Paulo, ao menos dentro do número de tropas que possuíam e foram registradas nos postos fiscais de Itapetininga e Rio Negro, local onde figuravam na lista dos maiores proprietários que cruzavam os registros, o que revelava 0 profundo envolvimento dos Pacheco com o negócio de tropas (SUPRINYAK, 2008, p. 43).

Dos citados no processo de justificação contra Condá, além dos irmãos Pacheco, o juiz municipal Antonio Alves de Oliveira e Manuel José Braga também eram negociantes de tropas. Todos os envolvidos (com exceção do escrivão) tinham segundas intenções no processo, assim como tinham um inimigo comum - Vitorino Condá. Clementino dos Santos Pacheco tinha um interesse maior ainda na petição contra Condá, já que era o único que estava ocupando terras no distrito

\footnotetext{
${ }^{7}$ Processo civil de justificação instaurado por Pedro de Siqueira Cortez na Vila Nova do Príncipe (Lapa) e oitiva das testemunhas em 09 de janeiro e 27 de janeiro de 1844. Seção Manuscritos. Ofícios diversos de Curitiba (1841-44). Caixa 209, pasta 4, documento 17, ordem 1004. APESP
} 
de Missões, em terras dos índios de Nonohay, próximo à estrada e aos lugares chamados de Mato Castelhano e Mato Português. Adiante segue seu testemunho:

Clementino dos Santos Paxeco homem branco casado e natural e morador nesta que vive de seo negócios de idade que disse ter trinta e seis anos Dice elle testemunha no primeiro artigo ser verdadeiro e geralmente sabido. Ao segundo Dice que hé verdade, por que tendo estado por varias vezes entre os Índios, tem visto entre elles muitos falando a lingoa Nacional e mestres de montar a cavallo, o que só sabem os Indios manços de Guarapuava. Ao terceiro disse que he crido geralmente que 0 indio Vithorino tem tomado parte nas incurssões dos índios na estrada do Sul e Distrito de Missoens. ${ }^{8}$

Do excerto acima além da resposta aos quesitos, em que as afirmativas responsabilizam os grupos Kaingang de Condá pelos assaltos na 'Estrada do Sul' e no distrito de Missões, uma das coisas que chama a atenção é a fala de Clementino que atesta haveria estado várias vezes entre os índios, tendo visto entre eles muitos falando a língua nacional e sendo mestres de montar a cavalo, o que só sabiam os índios mansos de Guarapuava. Embora tais palavras pareçam não ter um significado maior, elas reafirmam o fato já conhecido de que os índios de Vitorino Condá dominavam mais de um idioma, ao mesmo tempo em que atestam algo novo: esses índios se deslocavam a cavalo. Segundo esse depoimento, os índios de Condá possuíam cavalos e armas de fogo e deslocavam-se por uma extensa região. Porém, antes de tomarmos esse relato como verdade, é preciso cautela, lembrando que todas as afirmativas de Clementino faziam parte de um contexto em que Vitorino Condá era 0 alvo.

Antonio dos Santos Pacheco, o irmão mais velho, deu o seguinte depoimento:

Antonio dos Santos Paxeco, homem branco casado, natural e morador nesta que vive de seo negocio de idade que disse ter trinta e oito annos. Disse elle Testemunha no primeiro artigo que hé verdade todo nelle contido. Ao segundo disse que he verdade visto que tem se encontrado

\footnotetext{
${ }^{8}$ Depoimento de Clementino dos Santos Pacheco no processo civil de justificação instaurado por Pedro de Siqueira Cortez, na Vila Nova do Príncipe (Lapa), em 09 de janeiro e oitiva das testemunhas em 27 de janeiro de 1844. Seção Manuscritos. Ofícios diversos de Curitiba (1841-44). Caixa 209, pasta 4, documento 17, ordem 1004. APESP.
} 
entre os Indios que costumam atacar estes incursoens nos manços conhecidos serem os de Guarapuava. Ao terceiro disse que he falado geralmente, ser o Índio Vithorino quem derige os athaques que tem avido nos Mattos Portugues e Castelhano na estrada do Sul, assim como em diversos moradores no Districto de Missõens.

No depoimento, como se vê, o primogênito dos Pacheco afirma a existência de ataques, assaltos, roubos, pilhagens e sequestros a viajantes e moradores em Vacaria, no Mato Castelhano e Português, e no distrito das Missões. Ele também responsabiliza os índios comandados por Vitorino Condá. Os dois irmãos mais novos: David dos Santos Pacheco de 32 anos e Joaquim Pacheco da Silva Rezende de 29 anos (o único solteiro dos quatro irmãos), disseram em seu depoimento praticamente o mesmo: os índios mansos de Guarapuava e de Palmas tomavam parte nas incursões dos índios tanto nos Matos Castelhano e Português como na Estrada do Sul, e em diversos moradores no distrito de Missões. Também atestam que a crença geral era a de que Vitorino Condá comandava esses assaltos. ${ }^{10}$

0 que se percebe nos depoimentos era que não existiam, de fato, provas contundentes de que os assaltos cometidos a moradores e viajantes na Estrada do Sul e no distrito de Missões eram dirigidos por Vitorino Condá, o que se afirmava era a crença que geralmente se tinha dessa possibilidade. E isso se torna mais claro ao se observar o depoimento de Manuel José Braga, um também negociante de animais, natural de Itapetininga. Último a depor, ele apenas se manifesta nos termos que seguem:

Manuel José Braga homem branco, solteiro natural da Villa de Ithapetininga morador do Sul que vive de seos negócios de idade que disse ter trinta e nove annos. Dice elle testemunha ao primeiro Artigo

\footnotetext{
${ }^{9}$ Depoimento de Antonio dos Santos Pacheco no processo civil de justificação, instaurado por Pedro de Siqueira Cortez na Vila Nova do Príncipe (Lapa), em 09 de janeiro e oitiva das testemunhas em 27 de janeiro de 1844. Seção Manuscritos. Ofícios diversos de Curitiba (1841-44). Caixa 209, pasta 4, documento 17, ordem 1004. APESP.

${ }^{10}$ Depoimento de David dos Santos Pacheco e Joaquim Pacheco da Silva Resende no processo civil de justificação, instaurado por Pedro de Siqueira Cortez na Vila Nova do Príncipe (Lapa), em 09 de janeiro e oitiva das testemunhas em 27 de janeiro de 1844. Seção Manuscritos. Ofícios diversos de Curitiba (1841-44). Caixa 209, pasta 4, documento 17, ordem 1004. APESP.
} 
que hé verdade geralmente sabido, Ao segundo Dice que sabe por ouvir geralmente. ${ }^{11}$

Em relação ao comando dos assaltos, Manuel José Braga nada diz, ficando a acusação à Condá por conta dos irmãos Pacheco. Logo, é possível que 0 testemunho dos irmãos esteja muito mais ligado a necessidade de defender as terras ocupadas por um deles, Clementino, que havia invadido as terras indígenas nos campos de Nonohay. Também é possível que os depoimentos dos homens ligados à família Pacheco tivessem 0 intuito de desejar um livre deslocamento ao Continente do Sul, sem a presença ofensiva de índios que lutavam por seus lugares de morada e caça, como os Kaingang de Palmas.

Durante a década de 1840, Domingos Ignácio de Araújo era subdelegado em Palmeira. Quando de sua morte, em 1851, seus bens distribuídos por Palmeira e Ponta Grossa, chegavam a ser avaliados em mais de 218 contos de réis, uma riqueza considerável à época (LIMA, 2009). Em Palmeira, Domingos Ignácio usou de sua autoridade e por meio do cartório e do escrivão de paz e notas, Joaquim Ribeiro da Silva, foi encaminhada uma súplica de Pedro de Siqueira ao comandante do presídio de Guarapuava, Antonio da Rocha Loures, ao subdelegado Antonio de Sá e Camargo, também comandante do Esquadrão de Cavalaria Nacional e ao vigário da freguesia, o reverendo Antonio Braga de Araújo, parente de Domingos Ignácio. A súplica era composta de quatro quesitos que demonstro na citação:

Dis Pedro de Siqueira Cortez q' a elle Suplicante se faz preciso q.' V. S.a atteste 0 siguinte, 1.o Se os Índios rezidentes no Campo de Palmas e costa do Rio Pelotas tinhão vindo a este lugar e perpetrado assacinios em diferentes pessoas. 2.0 se os mesmos Índios tem tao bem, em Palmas matado gente nossa, 3.o Se o Índio Viturino tem deste distrito sahido deportado para outros lugares por causa de seos maos custumes, 4.0 se 0 mesmo Índio Viturino tem feito mortes em nossa gente e roubado na estrada desta Provincia Para 0 sul. ${ }^{12}$

\footnotetext{
${ }^{11}$ Depoimento de Manuel José Braga no processo civil de justificação, instaurado por Pedro de Siqueira Cortez na Vila Nova do Príncipe (Lapa), em 09 de janeiro e oitiva das testemunhas em 27 de janeiro de 1844. Seção Manuscritos. Ofícios diversos de Curitiba (1841-44). Caixa 209, pasta 4, documento 17, ordem 1004. APESP.

${ }^{12}$ Documentos juntados pelo escrivão do cartório de Palmeira, a mando do Capitão Domingos de Araújo na freguesia de Guarapuava e anexados em ofício ao Presidente da província, Manuel
} 
0 primeiro quesito da citação trata dos índios de Palmas e costas do rio Pelotas, bem como dos assaltos que seriam cometidos por estes a moradores e viajantes. Ao abordar Palmas e o rio Pelotas, inclui uma gama considerável de espaço e deslocamento, com uma consequente e significativa quantidade de índios e lideranças envolvidas. 0 segundo quesito pergunta se, também em Palmas, os índios cometeram assassinatos, enquanto que no terceiro quesito sobre Vitorino Condá, deseja-se saber se é verdade que Condá havia sido deslocado diversas vezes por seus maus costumes, sendo mais de uma vez deportado para lugares fora do distrito. No quarto e último quesito, o questionamento referia-se à dúvida se Vitorino matava e roubava na Estrada do Sul e em Guarapuava. 0 primeiro a declarar suas respostas aos quesitos foi Antonio de Sá e Camargo, subdelegado em Guarapuava:

0 Major Antonio de Sá e Camargo, Comandante do Esquadram de Cavalaria Nacional desta Fregresia, e Subdelegado de Pulicia da mesma. Atesto faço certo a quem o conhecimento desta aja de pertencer o seguinte q' os Índios moradores em Palmas e costa do Rio Pelotas, por veses tinhão neste distrito perpetrado ororosos assacinios em gente nosa que os mesmos Índios matarão emPalmas uns tantos indivíduos: que o Índio Victorino por causa de seo sempre péssimo procedimento tem por vezes sahido prezo deste para outras partes da Provincia: que o mesmoVictorino, 2.0 a vos Geral tem sempre presidido os asacinatos nos viajantes da estrada desta para a Provincia do Sul, e furtado os dinheiros dessas victimas, cujos dinheiros sempre o mesmo Victorino, e outros estão introduzindo na povoaçam de Palmas, eneste distrito: que mesmo Índio/ Vitorino. 2.0 consta por muitos lugares tem furtado uns tantos menores de familias residentes no distrito da Provincia do Rio Grande do Sul e os tem apresentado em Palmas. 0 referido he verdade. Guarapuava, 2 de abril $1844^{13}$

Antonio de Sá e Camargo era não só o subdelegado, mas também, o major comandante da Guarda Nacional, a força terrestre que substituía as antigas milícias. Nas respostas aos quesitos, além de confirmá-los, o major se adianta e

Felisardo de Souza e Mello, de 22 de maio de 1844. Seção Manuscritos. Ofícios diversos de Curitiba (1841-44). Caixa 209, pasta 4, documento 17, ordem 1004. APESP.

${ }^{13}$ Depoimento do Major Antonio de Sá e Camargo, Subdelegado de Guarapuava, na resposta a súplica de Pedro de Siqueira Cortez, em 02 de abril de 1844. Seção Manuscritos. Ofícios diversos de Curitiba (1841-44). Caixa 209, pasta 4, documento 17, ordem 1004. APESP. 
acrescenta que Vitorino presidia os assaltos, roubava dinheiro e crianças não indígenas, que fazia introduzir em Palmas. Também se pode observar que, mais uma vez, as acusações tem base, segundo o depoimento, "na voz pública". Ou seja, as acusações eram fundamentadas em considerações estruturadas dentro de uma opinião pública, dentro daquilo que, de forma geral, se ouvia dizer, ou do que falavam as pessoas.

Antonio da Rocha Loures, na sua resposta aos quesitos, além de concordar com eles, fazendo coro ao depoimento do subdelegado, acrescentou que era verdade que o índio Vitorino, por costumes sempre reprovados, foi por duas vezes preso e mandado para a cidade de São Paulo. 0 mesmo índio Vitorino, nas palavras do velho comandante, segundo a voz pública, dirigia os assaltos cometidos na Estrada do Sul, "donde resultou ter aparecido em poder do mesmo Vitorino, e de outros Índios, dinheiros roubados, e athé crianças arrancadas de gente noça naquelles actos horrorosos! 0 referindo he tudo verdade, e afirmo em fé de meo cargo". ${ }^{14}$

Antonio Braga de Araujo, vigário da igreja na freguesia de Belém de Guarapuava concordou com todos os quesitos, disse "que o Índio Victorino por seus costumes sempre maus tem por algumas veses sido lançado deste lugar para São Paulo, e mesmo para a Fortaleza de Santos". 15

0 que na verdade fica claro, é que os depoimentos de Antonio de Sá e Camargo e Antonio da Rocha Loures estavam diretamente ligados à questão que pretendiam ajudar a resolver, a reversão da pena que tinha sofrido Pedro de Siqueira Cortez, por ter comandado o assassinato de vinte e tantos índios inermes e que não esboçaram a menor reação - a demissão do comando do povoado de Palmas, que se não uma privação de liberdade, significava a privação de poder, deste e de seu aliado em Palmeira, o subdelegado Domingos Ignácio de Araújo. Nesse sentido, o fato primeiro que havia impulsionado 0 acontecimento dos assassinatos, foi Condá ter retornado com várias crianças brancas resgatadas de seus cativeiros junto aos Kaingang, assim, ao afirmar que Condá matava, roubava e raptava crianças brancas, para depois introduzir em Palmas, era como

\footnotetext{
${ }^{14}$ Depoimento de Antonio da Rocha Loures, no quartel da freguesia de Belém em Guarapuava, em 6 de abril de 1844. Seção Manuscritos. Ofícios diversos de Curitiba (1841-44). Caixa 209, pasta 4, documento 17, ordem 1004. APESP.

${ }^{15}$ Depoimento de Antonio Braga de Araujo, paróquia da freguesia de Belém de Guarapuava, 6 de abril de 1844. Seção Manuscritos. Ofícios diversos de Curitiba (1841-44). Caixa 209, pasta 4, documento 17, ordem 1004. APESP.
} 
desmentir toda a ação meritória de Condá e sua ascensão como comandante dos índios de Guarapuava e Palmas.

Para fechar o cerco antes de se encaminhar os documentos de justificação e súplica para a Presidência da província, foram juntados ainda três ofícios da época em que Pedro de Siqueira Cortez era comandante em Palmas e que ajudavam a compor o quadro necessário para a consecução de seus objetivos. Os dois primeiros documentos deveriam sair de dentro do povoado de Palmas, e foi 0 que aconteceu. Os documentos eram respostas a ordens dirigidas por Pedro de Siqueira, em janeiro de 1843, quando esse ainda era o comandante do povoado. Ordens dirigidas ao capelão do povoado de Palmas, Manuel Cabezas e o sargento do destacamento, Manuel Carlos Taborda, para que respondessem sobre uma diligência de índios e seus prisioneiros e que estavam em uma das fazendas de Hermógenes Carneiro Lobo Ferreira em Palmas (SOUZA, 2012).

0 último documento juntado pelo escrivão de Palmeira foi um ofício de Joaquim Fagundes dos Reis, capitão do presídio em Missões, sobre vários assaltos executados por indígenas às populações invasoras não indígenas, como em 1839, em que mataram vinte e três pessoas nas fazendas e ervais dos "Campos de Cima da Serra" ${ }^{16}$ A documentação organizada contra Condá foi anexada em ofício de Domingos Ignácio de Araújo ao presidente da província de São Paulo, em maio de $1844 .^{17}$

Dentro dessas condições está ocorrendo o processo contra 0 índio Vitorino Condá. A partir da documentação enviada, em maio, para 0 presidente da província de São Paulo, as condições de permanência de Condá na região de Palmas ficaram quase que insustentáveis. Talvez essas motivações e situações fizeram Vitorino Condá aceitar no ano de 1844, o convite de Francisco Ferreira da Rocha Loures, o primogênito do capitão, comandante do presídio em Guarapuava - Antonio da Rocha Loures, para realizar a tarefa de tornar possível e viável a "Estrada das Missões", o caminho entre Palmas e Cruz Alta na província de São Pedro (SOUZA, 2012). A missão para ter êxito deveria conseguir um salvo conduto pelos campos e terras indígenas, toda a região desde os campos de Palmas até a

\footnotetext{
${ }^{16}$ Ofício de Joaquim Fagundes dos Reis, Capitão do presídio em Passo Fundo, relatando assaltos, com muitas mortes e raptos realizados por indígenas nos ervais e fazendas da região dos campos de Cima da Serra. Seção Manuscritos. Ofícios diversos de Curitiba (1841-44). Caixa 209, pasta 4, documento 17, ordem 1004. APESP.

${ }^{17}$ Ofício de Domingos Ignácio de Araújo ao Presidente da província, Manuel Felisardo de Souza e Mello, de 22 de maio de 1844. Seção Manuscritos. Ofícios diversos de Curitiba (1841-44). Caixa 209, pasta 4, documento 17, ordem 1004. APESP.
} 
vila de Cruz Alta, na província de São Pedro do Rio Grande do Sul, era ainda morada de grupos indígenas considerados hostis pelos povoadores. Este salvo conduto, permitindo a abertura do novo caminho, abrindo um novo passo pelo Goyo-En, nos chamados Campos de Nonohay, era uma tarefa que só poderia ser executada com a ajuda de Vitorino Condá e o prestígio que detinha junto a aliados dessa região.

\section{CONSIDERAÇÕES FINAIS}

Em Palmeira, Guarapuava, Vila do príncipe (atual Lapa) e Palmas, fazendeiros e autoridades do governo no Brasil Império, em se tratando da ocupação dos territórios indígenas, juntavam forças e atuavam em prol de sua causa: expansão e ocupação das terras; aproveitamento da mão de obra indígena; aferição de lucros; enriquecimento com os negócios, com as benesses governamentais e com os cargos ocupados da administração pública (ORTELLI, 2007). Está em jogo o poder e 0 acesso às terras e, principalmente, do domínio sobre os campos nativos. Seguindo as palavras de Sérgio Buarque de Holanda, tornava-se imprescindível as alianças com os indígenas, personagens históricos desses lugares, cuja ausência de participação, inviabilizaria qualquer conquista (HOLANDA, 2008, p. 12). As terras em jogo passavam pelo apoio indígena, cada um (interessado na conquista) escolhia seus índios, e os índios escolhiam seus não indígenas, ou seja, cada um escolhia seu lado. Esses lados, em muitas vezes, mudavam de nomes e lugares, de acordo com as oportunidades e os interesses em jogo. Katia Graciela Jacques Menezes Malage, em sua dissertação de mestrado, intitulada Condá e Viri: Chefias indígenas em Palmas- PR, década de 1840, faz a analogia das tomadas de posição de Vitorino Condá com uma "placa giratória" (MALAGE, 2010, p. 91). A comparação é correta, mas deve ser acrescida de outras possibilidades (principalmente para análise de outras trajetórias), ao se pensar que a placa possui apenas dois lados, ou seja, Índios x Não Índios. Nesse caso, as possibilidades e caminhos atravessam a duplicidade e se encontram em áreas múltiplas, e com uma infinidade de posições assumidas. Vitorino Condá assim como a maioria das lideranças indígenas optaram entre a aliança, neutralidade, negociação, a dissimulação e o conflito (BRINGMANN, 2010). Acrescente-se para além de Sergio Buarque de Holanda, que a viabilidade da conquista não se tratava apenas pela presença indígena como uma experiência vivida do sertão, que em simbiose osmótica com o adventista invasor, permitia ao segundo melhor, dispor do meio que pretendia conquistar, mas também, porque em muitos casos fronteiriços, a maioria numérica das tropas indígenas colocava em dependência 
essa conquista, que só podia ser viabilizada por constantes alianças fundamentadas nesta supra e retro dependência.

\section{REFERÊNCIAS}

BANDEIRA, José Joaquim Pinto. Notícias da descoberta dos Campos de Palmas. Revista do Instituto Histórico e Geográfico Brasileiro, Rio de Janeiro, t. 14, p. 425-438, 1851. Disponível em: <http://www.ihgb.org.br/rihgb>. Acesso em: 20 mar. 2014.

BRINGMANN, Sandor Fernando. Índios, colonos e fazendeiros: conflitos interculturais e resistência Kaingang nas Terras Altas do Rio Grande do Sul (18291860). 2010. 219 f. Dissertação (Mestrado em História) - Centro de Filosofia e Ciências Humanas, Universidade Federal de Santa Catarina, Florianópolis.

HOLANDA, Sérgio Buarque de. Caminhos e fronteiras. São Paulo: Cia das Letras, 2008.

LIMA, Carlos A. M. Tráfico Ilegal para a fronteira agrária: Domingos Inácio de Araújo (Palmeira, 1830-1851). In: Anais do Encontro Escravidão e Liberdade no Brasil Meridional, 4, 2009.

MACHAD0, Antonio Claudio da Costa. Código de processo civil interpretado e anotado. Barueri: Manole, 2012. Seção IX - Da justificação, art. 861 a 866, p. 1537.

MALAGE, Kátia Graciela Jacques Menezes. Condá e Viri: chefias indígenas em Palmas - PR, década de 1840. 2010. 136 f. Dissertação (Mestrado em História) Setor de Ciências Humanas, Letras e Artes, Universidade Federal do Paraná, Curitiba, 2010.

MOTA, Lúcio Taudeu. Os índios Kaingang e seus territórios nos campos do Brasil meridional na metade do século passado. In: MOTA, Lúcio Tadeu; NOELLI, Francisco S.; TOMMASINO, Kimiye (Org.). Uri e Wãxi: Estudos interdisciplinares Kaingang. Londrina: Ed. UEL, 2000.

ORTELLI, Sara. Trama de una guerra conveniente: Nueva Viscaya y la sombra de los apaches. (1748-1790). México: Centro de Estudios Históricos, 2007. 
SOUZA, Almir Antonio de. Armas, pólvora e chumbo: a expansão luso-brasileira e os Índios do Planalto Meridional. 2012. 459 f. Tese (Doutorado em História) Centro de Filosofia e Ciências Humanas, Universidade Federal de Santa Catarina, Florianópolis.

SUPRINYAK, Carlos Eduardo. Tropas em marcha: o mercado de animais de carga no centro-sul do Brasil imperial. São Paulo: Annablume, 2008. 